\title{
EKSTRAKSI DAN KARAKTERISASI SERBUK NANO PIGMEN DARI DAUN TANAMAN JATI (TECTONA GRANDIS LINN. F)
}

\section{(EXTRACTION AND CHARACTERIZATION OF NANO PIGMENT POWDER FROM TEAK (TECTONA GRANDIS LINN. F) LEAVES)}

\author{
Riahna br Kembaren ${ }^{1}$, Sesotya Putriliniar ${ }^{1,2}$, Nurwenda Novan Maulana ${ }^{1,3}$, Kiki \\ Yulianto $^{1,3}$, Radyum Ikono ${ }^{1,4}$, Nurul Taufiqu Rochman ${ }^{1,5}$, Etik Mardliyati ${ }^{1,6}$ \\ ${ }^{1}$ Nano Center Indonesia, Komplek Puspiptek Serpong \\ ${ }^{2}$ Departemen Kimia, Universitas Jenderal Soedirman, Purwokerto \\ ${ }^{3}$ Departemen Teknologi Hasil Pertanian, Universitas Teknologi Sumbawa, Sumbawa Besar \\ ${ }^{4}$ Departemen Teknik Metalurgi dan Material, Universitas Teknologi Sumbawa, Sumbawa Besar \\ ${ }^{5}$ Pusat Penelitian Metalurgi LIPI, Komplek Puspiptek, Serpong \\ ${ }^{6}$ Pusat Teknologi Farmasi dan Medika BPPT, Komplek Puspiptek, Serpong \\ E-mail : rikono@nano.or.id
}

Received : 19 April 2013; revised : 03 Oktober 2013; accepted : 07 Oktober 2013

\begin{abstract}
ABSTRAK
Tanaman Jati (Tectona grandis linn. F) umumnya hanya dimanfaatkan bagian kayunya untuk industri meubel, namun bagian lain seperti daun kurang dimanfaatkan. Daun jati terutama bagian pucuk daun muda dapat menghasilkan pigmen. Produksi serbuk nano pigmen dari daun jati dan karakterisasi serbuk nano pigmen tersebut belum dilakukan. Tujuan penelitian ini adalah menghasilkan nano pigmen dari pucuk daun jati muda dalam bentuk serbuk dengan menggunakan persentase filler yang berbeda dan melakukan karakterisasi serbuk nano pigmen jati tersebut. Pucuk daun jati muda diberi perlakuan mekanik dengan penggerusan kemudian disaring, larutan yang diperoleh diukur partikelnya dengan Particle Size Analyzer (PSA), dan dikeringkan dengan penambahan filler maltodekstrin $5 \%$ dan $10 \%$. Serbuk yang diperoleh dihitung rendemen, ukuran partikel, dan kelarutan dalam air. Warna merah yang dihasilkan dari filtrat pucuk daun jati muda berasal dari zat warna antosianin yang terkandung dalam daun jati muda. Ekstrak dari pucuk daun jati muda memiliki ukuran dengan kisaran 87,8- 318,1 nm dengan ukuran rata-rata 109,2 nm. Hal ini menunjukkan bahwa ekstrak tersebut merupakan produk nano di alam. Penambahan filler dengan konsentrasi berbeda berpengaruh terhadap warna, rendemen, ukuran partikel serbuk, dan kelarutan pigmen serbuk dalam air.
\end{abstract}

Kata Kunci: Jati; Pigmen; Antosianin; Nano

\begin{abstract}
Teak plant (Tectonagrandis Linn.F) is widely used, mostly for its wood, in furniture industry. However, other parts such as leaves, are still underutilized. Teak leaves, especially the young shoots are able to produce pigment. Production of teak leaves nano pigments powder and pigment powder characterization has not been carried out. The purpose of this study was to produce nano pigment powder from young teak leaf using different filler percentage, and to characterize the pigment powder. Young teak leaf was treated with mechanical grinding and then filtered. The particle size analyzer (PSA) in solution obtained was measured with PSA. The solution was then dried with addition of $5 \%$ and $10 \%$ maltodextrin filler. The powder obtained was calculated for the yield, particle size, and solubility in water. The red color of young teak leaf filtrate derived from anthocyanin pigments contained in the young leaves of teak. Extract of young shoots have a size ranging from $87.8 \mathrm{~nm}$ to $318.1 \mathrm{~nm}$ with an average size of $109.2 \mathrm{~nm}$. This suggests that the extract is a natural product in nanoscale. The addition of filler with different concentrations affected the color, yield, particle size of the powder, and the pigment solubility in water.
\end{abstract}

Keywords: Teak; Pigment; anthocyanin; Nano 


\section{PENDAHULUAN}

Tanaman jati (Tectona grandis linn. F.) adalah jenis tanaman pohon tropis dengan distribusi yang luas di Asia Tenggara seperti Thailand, Laos, Burma, dan Indonesia. Di Indonesia, pulau Jawa adalah sentra penanaman jati. Tanaman jati juga tumbuh dengan baik di Bali dan Sumbawa. Potensi pemanfaaatan jati sangat besar di Indonesia. Pengelolaan hutan jati dilakukan oleh PT Perhutani yang mengelola hutan jati seluas 2,6 juta $H A$, namun pada umumnya pemanfaatan jati tersebut hanya pada bagian kayu dalam bentuk log untuk kebutuhan industri terutama industri furniture. Bagian lain dari jati seperti daun kurang dimanfaatkan secara efektif.

Daun jati muda memiliki kandungan beberapa senyawa pigmen terutama antosianin. Senyawa antosianin ini memberikan warna merah, ungu, hingga merah gelap. Antosianin merupakan senyawa flavonoid yang memiliki kemampuan sebagai antioksidan (Ariviani 2010). Pemanfaatan daun jati sebagai sumber pigmen dapat meningkatkan nilai ekonomis dan nilai guna daun tersebut. Pemanfaatan kandungan senyawa antosianin pada daun jati akan menghasilkan pigmen alami yang aman bagi kesehatan maupun lingkungan.

Pigmen sering dijumpai di pasaran dalam bentuk serbuk atau larutan, namun pigmen dalam bentuk serbuk memiliki kelebihan jika dibandingkan dengan larutan, yaitu lebih awet, ringan, volumenya lebih kecil sehingga dapat mempermudah dalam pengemasan dan pengangkutan atau distribusi. Pada produksi bahan yang berbentuk serbuk sering ditambahkan bahan pengisi (filler). Penambahan bahan pengisi perlu dilakukan untuk menurunkan kecenderungan bubuk melekat pada dinding pengering pada alat pengering (spray drying). Bahan yang dapat digunakan sebagai filler salah satunya adalah maltodekstrin. Maltodekstrin merupakan gula tidak manis dan berbentuk tepung berwarna putih dengan sifat larut dalam air. Maltodekstrin biasa digunakan sebagai filler dalam sediaan farmasi atau pangan (Hayati, et.al 2011). Perbedaan persentase filler yang digunakan dapat mempengaruhi karakteristik dari serbuk pigmen tersebut.

Tujuan penelitian ini adalah menghasilkan nano pigmen dari pucuk daun jati muda dalam bentuk serbuk dengan menggunakan persentase filler maltodekstrin yang berbeda dan melakukan karakterisasi serbuk pigmen jati tersebut. Manfaat penelitian ini adalah untuk memproduksi nano pigmen alami dan mengetahui karakteristik pigmen yang terdapat dalam daun jati sehingga dapat digunakan sebagai sumber pigmen alami. Ukuran nanometer dari suatu partikel menyebabkan mampu melewati biological barrier, memperbaiki tingkat penerimaan jaringan tubuh dan meningkatkan penyerapan dan transportasi seluler (Sozer dan Kokini, 2009).

\section{BAHAN DAN METODE}

\section{Alat dan Bahan}

Bahan yang digunakan adalah pucuk daun jati muda yang diperoleh dari taman di kawasan Pusat Penelitian IImu Pengetahuan dan Teknologi, Serpong. Air, maltodekstrin dan butiran silika (silika gel). Alat yang digunakan adalah mortar, gelas kaca, kertas saring, kain saring, gelas ukur, spray drying, tabung reaksi, aluminium foil, dan pipet tetes.

\section{Metode}

\section{Rendemen volume ekstrak dari daun muda}

Pucuk daun jati muda dicuci dengan air terlebih dahulu, setelah itu pucuk daun ditimbang, kemudian digerus hingga halus dan menghasilkan cairan. Hancuran dari daun jati diperas dan disaring kemudian ditampung dalam wadah gelas kaca. Cairan atau larutan hasil gerusan yang telah dikumpulkan dihitung volumenya, lalu dihitung rendemen volume larutan dari setiap gram sampel pucuk daun jati muda yang digunakan. Setelah tahap tersebut, larutan dibungkus dengan aluminum dan disimpan dalam freezer.

\section{Pengeringan ekstrak daun jati}

Larutan hasil perasan dikeringkan menggunakan alat pengering spray drying di laboratorium LABTIAP BPPT Puspiptek Serpong. Pada pengeringan tersebut dilakukan penambahan filler maltodekstrin dengan persentase $5 \%$ dan $10 \%$ ke dalam larutan tersebut. Suhu inlet yang digunakan $180^{\circ} \mathrm{C}$, suhu exhaust $109^{\circ} \mathrm{C}$ dengan kecepatan pompa 3.5 liter/menit. Setelah proses pengeringan selesai, serbuk ditimbang dan dilakukan perhitungan rendemen. Serbuk yang dihasilkan dengan penambahan filler maltodekstrin $5 \%$ dan $10 \%$ diamati warna yang dihasilkan. Serbuk tersebut kemudian disimpan dalam wadah yang mengandung butiran silika. 


\section{Pengukuran diameter ukuran partikel}

Larutan hasil dari penggerusan dan pemerasan diukur diameter partikelnya menggunakan Particle Size Analyzer (PSA) merk Beckman Coulter yang dilakukan di Nano Center Indonesia di Puspiptek, Serpong. Karakterisasi dengan PSA dilakukan pada suhu $25^{\circ} \mathrm{C}$ menggunakan pelarut air, indeks bias 1.3328, dan derajat viskositas $0.8878 \mathrm{cP}$. Setelah proses pengeringan dengan alat pengering spray drying, serbuk diukur ukuran diameter partikelnya dengan instrumen PSA.

\section{Pengukuran kecepatan larut serbuk (Resuspensi serbuk)}

Serbuk yang diperoleh dari pengeringan dengan penambahan maltodekstrin 5\% dan $10 \%$ dilarutkan dalam media air, lalu dihitung waktu yang dibutuhkan oleh serbuk untuk larut sempurna.

\section{HASIL DAN PEMBAHASAN}

\section{Rendemen ekstrak dari pucuk daun jati} muda

Pucuk daun jati muda yang diberi perlakuan mekanik dengan penggerusan menyebabkan pengeluarkan cairan atau larutan berwarna merah kecoklatan dari sampel daun tersebut (Gambar 1). Warna merah kecoklatan yang dihasilkan dari filtrat daun jati muda berasal dari zat warna antosianin yang dikandung daun muda jati (Artati, et.al 2009). Pigmen antosianin terdapat dalam cairan sel tumbuhan, senyawa ini berbentuk glukosida dan menjadi penyebab warna merah kecoklatan. Ketika diberi perlakuan mekanik dengan penggerus, sel pada jaringan pucuk daun jati muda mengalami kerusakan rusak atau pecah sehingga cairan dalam sel keluar, dan menghasilkan filtrat yang berwarna merah. Dari 10 gram pucuk daun jati muda yang digunakan dapat diperoleh $7 \mathrm{ml}$ cairan atau larutan berwarna merah kecoklatan sehingga rendemen ekstrak adalah $70 \% \mathrm{v} / \mathrm{b}$.

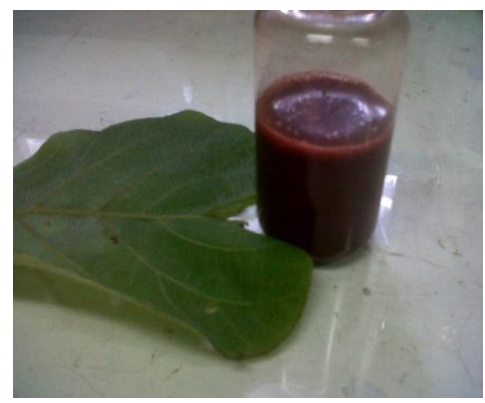

Gambar 1. Hasil penggerusan daun jati menjadi pigmen cair berwarna merah.
Bagian daun yang digunakan pada penelitian ini adalah pucuk daun jati muda. Penggunaan pucuk daun jati muda tersebut menghasilkan warna yang lebih merah jika dibandingkan dengan daun tua dikarenakan kandungan pigmen antosianin yang lebih tinggi. Selain itu jaringan pucuk daun jati muda yang belum mengeras dan memiliki kandungan air yang lebih tinggi menyebabkan bagian daun tersebut lebih mudah digerus.

\section{Ukuran partikel ekstrak}

Hasil dari pengukuran ukuran partikel menggunakan particle size analyzer ( $P S A)$ pada ekstrak pucuk daun jati muda diperoleh ukuran diameter partikel dengan kisaran 87.8- 318.1 $\mathrm{nm}$, dengan ukuran rata-rata $109.2 \mathrm{~nm}$. Hasil PSA tersebut dapat dilihat pada gambar 2. Hasil ini menunjukkan bahwa ekstrak pucuk daun jati muda merupakan produk nano di alam.



Gambar 2. Grafik hasil pengukuran ekstrak dari Pucuk Daun Jati Muda dengan PSA

\section{Pengeringan}

Pada pengeringan dengan penambahan maltodekstrin 5\% diperoleh serbuk pigmen berwarna merah. Bobot serbuk pigmen yang didapatkan adalah $4.264 \mathrm{gram}$ dan rendemen yang diperoleh adalah $3.05 \% \mathrm{~b} / \mathrm{v}$. Rendemen serbuk pigmen yang diperoleh cukup rendah, hal ini dapat dikarenakan konsentrasi padatan terlarut pada ekstrak pucuk daun jati muda rendah dan kandungan air yang tinggi, sehingga ketika dikeringkan, air menguap dan menyebabkan penyusutan bobot (Sembiring 2009).

Pada pengeringan dengan penambahan maltodekstrin $10 \%$ diperoleh serbuk pigmen dengan bobot sebesar 9.275 gram dan rendemen yang diperoleh adalah $6.63 \% \mathrm{~b} / \mathrm{v}$. 
Rendemen serbuk yang diperoleh dengan penambahan maltodekstrin $10 \%$ lebih tinggi dibandingkan maltodekstrin 5\% karena jumlah padatan terlarut yang lebih banyak akibat penambahan konsentrasi maltodekstrin yang lebih tinggi. Penambahan maltodekstrin dengan konsentrasi yang berbeda tersebut juga berdampak kepada tingkat warna pada serbuk pigmen. Serbuk dengan penambahan maltodekstrin $10 \%$ memiliki tingkatan warna yang lebih rendah yaitu sedikit merah jika dibandingkan dengan serbuk dengan penambahan maltodekstrin 5\% (Gambar 3).

Pemberian (bahan pengisi) filler yang lebih tinggi dapat menutupi warna tersebut sehingga intensitas warna menurun. Serbuk yang diperoleh disimpan dalam wadah yang mengandung butiran silika dengan tujuan memperpanjang umur simpan dan mencegah serbuk higroskopis.

Bahan pengisi (filler) berfungsi melapisi komponen antosianin tersebut dan mempercepat proses pengeringan sehingga mencegah dan mengurangi kerusakan antosianin akibat panas. Selain itu penambahan filler meningkatkan jumlah total padatan pada ekstrak. Dari hasil pengeringan, terbukti bahwa spray drying mampu menghasilkan serbuk yang kering dan bentuk yang baik.

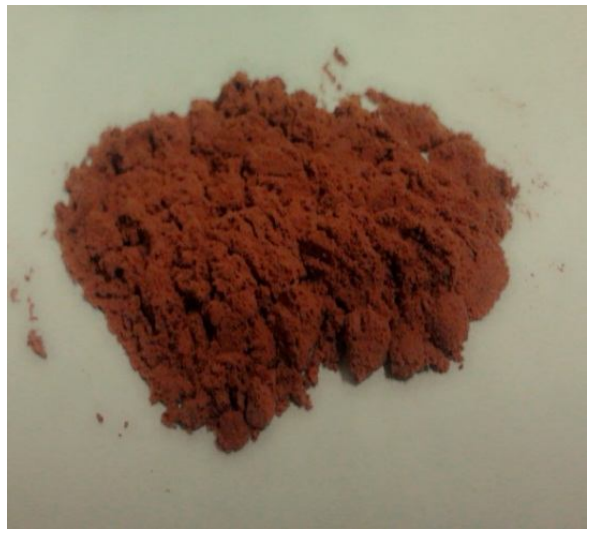

(a)

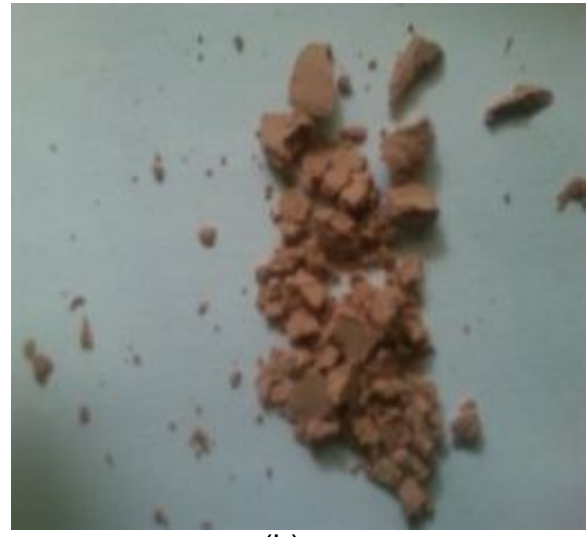

(b)

\section{Ukuran Partikel Serbuk}

Serbuk pigmen yang telah diperoleh kemudian diukur diameter ukuran partikel menggunakan PSA dan didapatkan ukuran diameter partikel ekstrak jati setelah dikeringkan dalam bentuk serbuk dengan filler $5 \%$ adalah 265.1- $950.9 \mathrm{~nm}$, dengan ukuran rata-rata 331.4 nm (Gambar 4).

Ukuran diameter partikel ekstrak jati setelah dikeringkan dalam bentuk serbuk dengan penambahan maltodekstrin $10 \%$ adalah $323.3-1231.1 \mathrm{~nm}$, dengan ukuran rata-rata 405.5 $\mathrm{nm}$ (Gambar 5)

Ukuran serbuk dengan penambahan filler $10 \%$ lebih besar dibandingkan dengan filler $5 \%$. Hal ini menunjukkan bahwa penambahan filler dapat meningkatkan ukuran partikel serbuk, namun penambahan filler tidak menambah ukuran partikel dalam jumlah yang signifikan (masih dalam ukuran nanometer). Distribusi ukuran diameter partikel nano pigmen yang diperoleh cukup luas, hal ini disebabkan oleh adanya agregasi partikel nano pigmen dan bahan pengisi, beberapa partikel nano pigmen dan bahan pengisi berinteraksi satu sama lain (Kim,et al. 2006). Upaya yang dapat dilakukan untuk menghomogenkan distribusi ukuran diameter partikel nano pigmen adalah dengan penambahan konsentrasi surfaktan, ultrasentrifugasi, dan penggunaan tekanan tinggi.

Gambar 3 .a) Serbuk pigmen dengan filter maltodekstrin 5\%, b) Serbuk pigmen maltodekstrin 10\% 


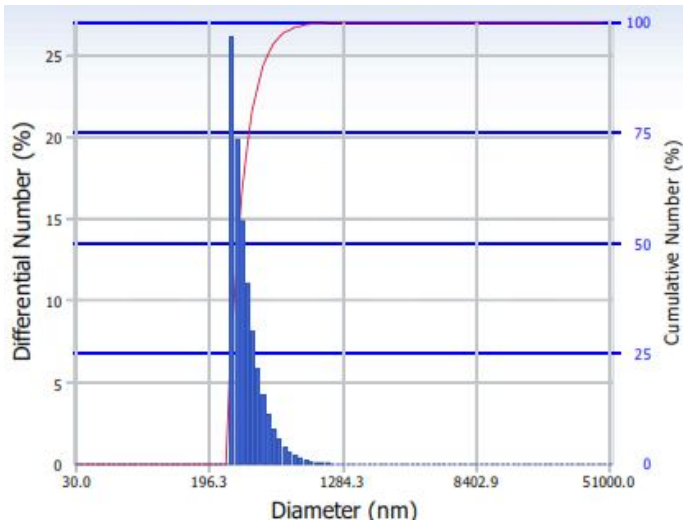

Gambar 4. Grafik hasil pengukuran ekstrak dari Pucuk Daun Jati Muda dengan penambahan filler $5 \%$

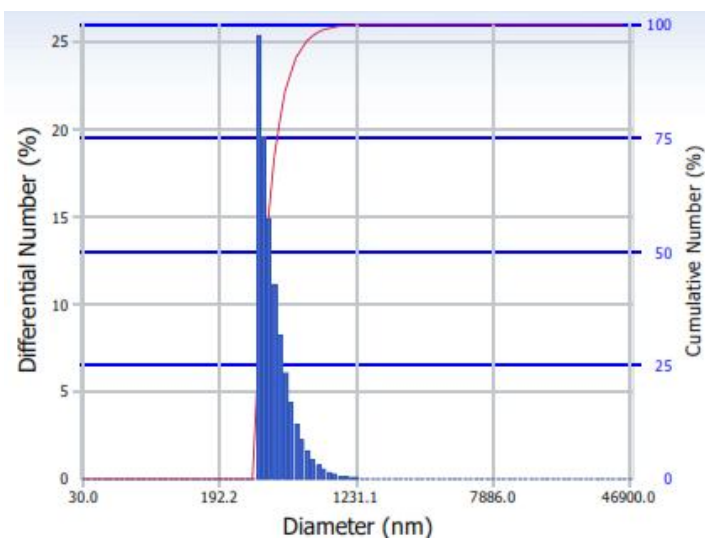

Gambar 5. Grafik hasil pengukuran ekstrak dari Pucuk Daun Jati Muda dengan penambahan filler $10 \%$

\section{Laju kelarutan serbuk pigmen}

Sebanyak $0.1 \mathrm{gr}$ serbuk pigmen dengan penambahan maltodekstrin $5 \%$ setelah ditambahkan $3 \mathrm{ml}$ aquadest membutuhkan waktu 37 detik oleh serbuk untuk larut dengan sempurna. Pada serbuk pigmen dengan penambahan maltodekstrin $10 \%$ setelah dilarutkan dalam aquadest membutuhkan waktu 52 detik untuk dapat larut dengan sempurna. Hal ini menunjukkan bahwa penambahan filler dan konsentrasi filler berpengaruh terhadap kelarutan serbuk dalam media air. Selain itu, ukuran partikel serbuk juga memiliki pengaruh terhadap kelarutan dalam media air. Semakin kecil partikel serbuk tersebut, semakin mudah terdispersi dalam air karena ukuran partikel pada ukuran submikro atau nano dapat meningkatkan tingkat dispersi serbuk dalam air (Hoang, et.al 2011). Oleh karena hal tersebut, Serbuk pigmen dengan maltodekstrin $5 \%$ yang memiliki ukuran partikel yang lebih kecil lebih cepat larut dalam air.

Perbedaan konsentrasi filler yang digunakan juga berpengaruh terhadap warna yang dihasilkan oleh larutan pigmen ketika serbuk pigmen tersebut dilarutkan dalam media air. Larutan dari serbuk pigmen dengan penambahan maltodekstrin $5 \%$ memiliki intensitas warna merah yang lebih tinggi dibandingkan dengan penambahan maltodekstrin 10\% (Gambar 6). Warna putih pada maltodekstrin dapat menurunkan intensitas warna dari ekstrak pucuk daun jati muda.

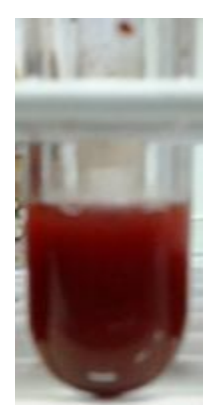

(a)

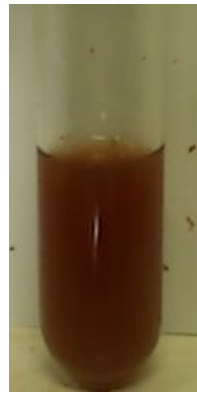

(b)
Gambar 6. Larutan dari serbuk pigmen dengan (a) maltodekstrin $5 \%$ dan (b) maltodekstrin $10 \%$.

\section{KESIMPULAN}

Daun jati muda memiliki kandungan antosianin dan dapat diproduksi menjadi serbuk pigmen. Penambahan filler maltodekstrin $5 \%$ menghasilkan serbuk pigmen dengan tingkatan warna yang lebih tinggi, ukuran partikel serbuk yang lebih kecil dan kelarutan dalam air yang lebih cepat namun rendemen yang lebih rendah jika dibandingkan serbuk pigmen dengan penambahan filler maltodekstrin $10 \%$. Diperlukan penelitian lanjutan untuk mengetahui kadar antosianin di dalam pigmen dan juga aplikasi pigmen pada objek makanan, pupuk, dan lainnya sehingga proses optimasi bisa dilakukan.

\section{DAFTAR PUSTAKA}

Anselman, R. 2001. Nanoparticles and nanolayers in commercial applications. 2001. Journal of Nanoparticle Research 3 : 329-336.

Ariviani, S. 2010. Total antosianin ekstrak buah salam dan korelasinya dengan 
kapasitas anti peroksidasi pada sistem linoelat. AGROINTEK 4(2) : 121-127.

Ati, N.H., P. Rahayu, S. Notosoedarmo dan L. Limantara. 2006. Komposisi dan Kandungan Pigmen Tumbuhan Pewarna Pigmen Alami Tenun Ikat di Kabupaten Timor Tengah Selatan, Propinsi Nusa Tenggara Timur.Indo. J. Chem. 6(3): 325-331.

Ariviani, S. 2010. Total antosianin ekstrak Buah salam dan Korelasinya dengan kapasitas anti peroksidasi pada sistem linoelat. AGROINTEK 4:121-127.

Hayati, S.N, H. Herdian, E. Damayanti, L. Istiqomah dan Julendra H. 2011. Profil asam amino ekstrak cacing tanah (LUMBRICUS

RUBELLUS) Terenkapsulasi dengan metode spray drying. Jurnal Teknologi Indonesia 34: 1-7.

Hoang, L. C., R. Fougere dan Y.Wache. 2011. Increase in stability and change in supramolecular structure of $\beta$-carotene through encapsulation into poly lactic acid nanoparticles. Food Chemistry 124: 42-49.

Kim, D.G., Y.I. Jeong, C.Y. Choi, S. H.Roh, S.K. Kang, M.K. Jang and J.W. Nah. 2006.
Retinol-encapsulated low molecular water soluble chitosan nanoparticles. International Journal of Pharmaceutics 319: 130-138.

Reis C.P., R.J. Neufeld, A.J. Ribeiro and F. Veiga. 2006. Nanoencapsulation I. Methods for preparing of drug loaded polymeric nanoprticles. Nanomedicine (2): $8-21$

Sembiring, B. 2009. Pengaruh konsentrasi bahan pengisi dan cara pengeringan terhadap mutu ekstrak kering sambiloto. Bul. Littro 20(2): 173-181.

Sozer, N , J.L. Kokini . 2009. Nanotechnology and its application in the food sector. Cell Press 27(2): 82-89.

Tachaprutinum, A., T. Udomsup, C. Luadthong and S. Wanichwecharungruang. 2009. Preventing the thermal degradation of Astaxanthin through nanoencapsulation. International Journal of Pharmaceutics 374 : 119124.

Yuan, J., S. Zhou, B. You and L. Wu . 2005. Organic pigment particles coated with collodial nano-silica particles via layerby-layer assembly. Chem. Mater. 17(14): 3587-3594. 